\title{
Эффекты производных адамантана на поведенческую активность мышей на разных стадиях экспериментального паркинсонического синдрома
}

\author{
Воронина Н.А. ${ }^{1}$, Кучеряну В.Г. ${ }^{1}$, Капица И.Г. ${ }^{2}$, Воронина Т.А.
}

\footnotetext{
${ }^{1}$ Федеральное государственное бюджетное научное учреждение

«Научно-исследовательский институт общей патологии и патофизиологии».

125315, Москва, ул. Балтийская, д. 8

${ }^{2}$ Федеральное государственное бюджетное научное учреждение

«Научно-исследовательский институт фармакологии имени В.В. Закусова»,

125315, Москва, ул. Балтийская, д. 8
}

Ключевым звеном патогенеза болезни Паркинсона (БП) является гибель дофаминергических нейронов в черной субстанции, вызывающая резкое снижение уровня дофамина в стриатуме головного мозга. Длительное терапевтическое применение предшественника дофамина L-ДОФА приводит к развитию тяжелых побочных эффектов и прогрессированию заболевания. Новый антипаркинсонический препарат, производный адамантана - гимантан (N-(2-адамантил)-гексаметиленимина гидрохлорид) обладает нейропротекторными и противовоспалительными свойствами. Цель работы: провести сравнительное изучение влияния производных адамантана - гимантана и амантадина на параметры локомоторной активности мышей на разных стадиях развития паркинсонического синдрома (ПС). Материал и методы. Эксперименты проводили на мышах-самцах линии C57BI/6 (n= 98) в возрасте 3-4 месяцев и массой тела 22-24 г. Стадии (начальную, среднюю и позднюю) ПС моделировали внутрибрюшинным введением нейротоксина1-метил-4-фенил-1,2,3,6-тетрагидропиридина (МФТП) однократно (в дозе 16 мг/кг, 30 мг/кг, 40 мг/кг), или многократно (4 раза по 12 мг/кг или 4 раза по 20 мг/кг с интервалом 2 часа). Гимантан и амантадин гидрохлорид (мидантан) вводили животным в дозе 20 мг/кг однократно за 30 мин до введения МФТП, или 4 раза при многократном введении нейротоксина. Развитие ПС оценивали по выраженности мышечной ригидности и изменению двигательной активности животных.

Результаты. Показано, что введение гимантана и амантадина увеличивало длину пробега, число стоек мышей, а также снижало выраженность ригидности и степень нарушения координации движений животных с ПС, вызванным МФТП в дозе 16 мг/кг (однократно) и $4 \times 12$ мг/кг (многократно). При этом эффекты гимантана были более выраженными в сравнении с эффектами амантадина. Антипаркинсонический эффект обоих препаратов был слабее на промежуточной стадии ПС, вызванного однократным введением МФТП в дозе 30 мг/кг, и отсутствовал на поздней стадии ПС, вызванного многократным введением МФТП в дозе $4 \times 20$ мг/кг. Заключение. В сравнении с амантадином гимантан при предварительном введении более эффективно предупреждал снижение двигательной активности, нарушение координачии движения и развитие ригидности животных на ранней стадии развития ПС.

Ключевые слова: болезнь Паркинсона; паркинсонический синдром; производные адамантана; поведение; МФТП; мыши.

Для цитирования: Воронина Н.А., Кучеряну В.Г., Капица И.Г., Воронина Т.А. Эффекты производных адамантана на поведенческую активность мышей на разных стадиях экспериментального паркинсонического синдрома. Патогенез. 2019; 17(4): 57-62

DOI: $10.25557 / 2310-0435.2019 .04 .57-62$

Для корреспонденции: Кучеряну Валериян Григорьевич, e-mail: vkucheryanu@mail.ru Финансирование. Исследование не имеет спонсорской поддержки.

Конфликт интересов. Авторы заявляют об отсутствии конфликта интересов.

Поступила: 10.09.2019

\section{Effects of adamantane derivatives on behavioral activity of mice with different stages of experimental parkinsonian syndrome}

\author{
Voronina N.A. ${ }^{\text {, }}$ Kucheryanu V.G. ${ }^{\text {, }}$ Kapitsa I.G. ${ }^{2}$, Voronina T.A. ${ }^{2}$
}

\begin{abstract}
${ }^{1}$ Institute of General Pathology and Pathophysiology,
Baltijskaya Str. 8, Moscow 125315, Russian Federation

${ }^{2}$ V.V.Zakusov Institute of Pharmacology,

Baltijskaya Str. 8, Moscow 125315, Russian Federation
\end{abstract}

A key element in the pathogenesis Parkinson's disease (PD) is death of dopaminergic neurons in substantia nigra, which leads to a sharp decrease in striatal concentration of dopamine. Long-term use of levodopa-containing drugs results in severe side effects and the disease progression. A new antiparkinsonian drug, the adamantine derivative, hemantane ( $N$-(2-adamantyl)-hexamethyleneimine hydrochloride), has neuroprotective and anti-inflammatory features.

Objective: To compare effects of hematane and amantadine on locomotor activity of mice at different stages of the parkinsonian syndrome (PS).

Methods. Experiments were performed on C57BI/6 male mice $(n=98)$ aged 3-4 months and weighing $22-24 \mathrm{~g}$. The stages (early stage, mid-stage, and advanced stage) of parkinsonian syndrome (PS) were simulated in C57BI/6 mice by intraperitoneal 
injections of a neurotoxin, 1-methyl-4-phenyl-1,2,3,6-tetrahydropyridine (MPTP), either at a single dose of $16 \mathrm{mg} / \mathrm{kg}, 30 \mathrm{mg} / \mathrm{kg}$, and $40 \mathrm{mg} / \mathrm{kg}$, or repeatedly, 4 times at $12 \mathrm{mg} / \mathrm{kg}$ or 4 times at $20 \mathrm{mg} / \mathrm{kg}$ at 2-h intervals. Gimantan and amantadine hydrochloride (midantan) were administered to animals at a single dose of $20 \mathrm{mg} / \mathrm{kg} 30$ minutes prior to MPTP administration or 4 times with the repeated administration of the neurotoxin. The development of PS was detected by muscle rigidity and changes in motor activity.

Results. Administration of either hematane or amantadine increased the distance traveled and the number of rearings, and also reduced severity of the rigidity and impairment of movement coordination when PS was induced by a single injection of MPTP 16 $\mathrm{mg} / \mathrm{kg}$ and repeated injections of MPTP $4 \times 12 \mathrm{mg} / \mathrm{kg}$. Furthermore, the effects of gimantan were more pronounced in comparison with the effects of amantadine. The antiparkinsonian effect of both drugs was weaker at the mid-stage of PS caused by a single injection of MPTP $30 \mathrm{mg} / \mathrm{kg}$ and was absent at the advanced stage of PS caused by repeated injections of MPTP $4 \times 20 \mathrm{mg} / \mathrm{kg}$. Conclusion. Compared to amantadine, the prior administration of gimantan more effectively prevented the decrease in motor activity, impaired coordination of movements and development of stiffness in animals at the early stage of PS.

Key words: Parkinson's disease; parkinsonian syndrome; derivatives of adamantine; behavior; MPTP; mice

For citation: Voronina N.A., Kucheryanu V.G., Kapitsa I.G., Voronina T.A. [Effects of adamantane derivatives on behavioral activity of mice with different stages of experimental parkinsonian syndrome]. Patogenez. [Pathogenesis]. 2019; 17(4): 57-62 (in Russian)

DOI: $10.25557 / 2310-0435.2019 .04 .57-62$

For correspondence: Kucheryanu Valerian Grigorevich, e-mail: vkucheryanu@mail.ru

Funding. The study had no sponsorship.

Conflict of interest. The authors declare no conflict of interest. Received: 10.09.2019

Болезнь Паркинсона (БП) является тяжелым, весьма распространённым нейродегенеративным заболеванием центральной нервной системы, часто приводящим к развитию инвалидности [1]. В группу риска входят люди в возрасте от 40 лет. Среди людей в возрасте более 65 лет больные БП составляют 2-3\% от общей популяции [2]. Самый высокий процент заболевших отмечается в возрасте старше 80 лет и составляет 5-10\%. Ключевым звеном патогенеза БП является гибель дофаминергических нейронов в черной субстанции, вызывающая резкое снижение уровня дофамина в стриатуме головного мозга $[1,3]$. В настоящее время основным методом лечения БП является заместительная терапия в виде предшественника дофамина L-ДОФА. Однако данная терапия является симптоматической и не направлена на устранение главной причины заболевания - дегенерации нигральных дофаминергических нейронов. К тому же, длительное применение леводопа-содержащих препаратов приводит к развитию тяжелых побочных эффектов и прогрессированию заболевания.

В качестве средств лечения БП применяют производные адамантана - препараты амантадин и глудантан $[1,4,5]$. Показано, что новый препарат гимантан (N-(2-адамантил)-гексаметиленимина гидрохлорид) в культуре клеток нейробластомы человека SH-SY5Y снижает цитотоксичность, индуцированную нейротоксином 6-гидроксидофамина (6-ГОДА), оказывая цитопротекторный эффект [6]. На модели досимптомной стадии болезни Паркинсона, вызванной билатеральным интранигральным введением нейротоксина 1-метил-4-фенил-1,2,3,6-тетрагидропиридина (МФТП) в дозе 100 мкг крысам, гимантан (10 мг/кг) препятствовал развитию когнитивных нарушений и депрессивно-подобного поведения животных [7]. На модели гемипаркинсонического синдрома, вызван- ного с помощью одностороннего интрацеребрального введения 6-ГОДА у крыс, гимантан проявил выраженное противопаркинсоническое действие, снижая степень акинезии передней конечности, и увеличивал длину шага животных [8]. На МФТП-индуцированной модели паркинсонизма у мышей показано, что эффективность подавления паркинсонической симптоматики применением гимантана в комбинации с агонистом дофаминовых рецепторов пирибедилом была выше, чем у препаратов по отдельности [9].

Целью данных исследований явилось сравнительное изучение влияния производных адамантана - гимантана и амантадина - на параметры локомоторной активности мышей на разных стадиях развития паркинсонического синдрома (ПС).

\section{Материалы и методы исследования}

Эксперименты проводили на мышах-самцах линии C57Bl/6 $(n=98)$ в возрасте 3-4 месяцев и массой тела 22-24 г. Животные содержались в стандартных условиях вивария при свободном доступе к воде и пищи и 12-часовом световом режиме. В экспериментальных группах было 8-10 животных. При выполнении экспериментальных работ соблюдались требования, изложенные в Директивах Совета Европейского сообщества 86\609\ЕЕС об использовании животных для экспериментальных исследований, что подтверждено заключением Этического комитета ФГБНУ НИИОПП, протокол №4 от 02.09.2019.

Стадии (начальную, среднюю и позднюю) ПС моделировали внутрибрюшинным введением МФТП однократно (в дозе 16 мг/кг, 30 мг/кг, 40 мг/кг), или многократно (4 раза по 12 мг/кг или 4 раза по 20 мг/кг с интервалом 2 часа). При введении МФТП мышам по схеме $4 \times 12$ мг/кг моделируется ранняя клиническая 
стадия болезни Паркинсона, а при введении нейротоксина в режиме $4 \times 20$ мг/кг моделируется выраженная поздняя клиническая стадия БП [10].

Для оценки олигокинезии определяли горизонтальную и вертикальную двигательные активности животных, которые измеряли в автоматизированном режиме посредством установки (Opto-Varimex-3) фирмы «Columbus Instruments» (USA), используя программу «Auto-Track». Длительность тестирования животных составила 6 мин. Для оценки моторного дефицита и степени нарушения координации движений у мышей использовали тест «вертикальный стержень» (Pole test). Степень развития ригидности определяли по длине шага (Stride Length Test) и симптому «горбатости» и выражали в баллах $[11,12]$.

Препараты, гимантан (синтезирован в НИИ фармакологии имени В.В. Закусова) и амантадин гидрохлорид (мидантан, Борисовский ЗМП, Беларусь), вводили животным в дозе 20 мг/кг однократно за 30 мин до введения МФТП, или 4 раза при многократном введении нейротоксина. Тестирование животных проводили спустя 1 час в случае введения МФТП однократно, и спустя 2 недели при многократном введении нейротоксина.

Статистический анализ результатов проводили с использованием алгоритмов компьютерной программы STATISTICA 10.0: для определения нормального характера распределения данных использовали тест Колмогорова-Смирнова; межгрупповые различия анализировали с помощью однофакторного дисперсионного анализа One-Way ANOVA с пост-хок тестом Ньюмена-Куллза. Отличия считали достоверными при $p<0,05$.

\section{Результаты исследования}

Однократное введение МФТП приводило к развитию олигокинезии и мышечной ригидности, выраженность которых увеличивалась с повышением дозы нейротоксина.

Гимантан, как и амантадин, при предварительном введении препятствовали развитию негативных эффектов МФТП. Параметры локомоторной активности мышей при предварительном введении гимантана были выше, чем в группе с ПС: горизонтальная активность (длина пробега) составляла соответственно $487 \pm 11,4$ и $157 \pm 16$ см $(p<0,05)$, вертикальная активность (число стоек) - 6,7 $\pm 0,9$ и 1,8 $\pm 0,8(p<0,01)$. У животных с предварительным введением амантадина длина пробега составила $2531 \pm 14$ см, что значимо больше, чем у животных с ПС, но значимо меньше, чем у животных с предварительным введением гимантана (в обоих случаях $p<0,05$ ). Число стоек при введении амантадина составило $3,1 \pm 0,4$, что также значимо отличалось от обеих групп сравнения $(p<0,05)$.

Показатели ригидности составили 1,7 \pm 0,1 балла в группе животных, которым однократно ввели МФТП в дозе 16 мг/кг (животные с ПС); 0,6 \pm 0,1 балл при предварительном введении гимантана (отличия от группы с ПС значимы: $p<0,01) ; 1,1 \pm 0,2$ балла при предварительном введении амантадина (отличия от других групп статистически значимы: $p<0,01$ при сравнении с группой МФТП, $p<0,05$ при сравнении с группой МФТП+гимантан).

У животных с ПС, вызванным МФТП в дозе 30 мг/ кГ антипаркинсонический эффект гимантана и амантадина был менее выражен, а в дозе 40 мг/кг - отсутствовал.

При моделировании ранней клинической стадии паркинсонического синдрома путем многократного введения МФТП $(4 \times 12$ мг/кг, Гр.2), спустя 2 недели наблюдали достоверное снижение горизонтальной и вертикальной двигательной активностей мышей, увеличение времени, когда животное оставалось без движения, и времени спуска животного в тесте «вертикальный стержень», что свидетельствовало о возникновении олигокинезии и нарушении координации движений. При этом у животных развивалась лёгкая степень ригидности, выраженность которой составила $1,5 \pm 0,1$ балла, а длина шага снижалась с $6,7 \pm 0,1$ см до $5,1 \pm 0,2$ см $(p<0,01)$ (рис.).

Предварительное введение гимантана (Гр.3-1) увеличивало горизонтальную двигательную активность (длину пробега) с $305 \pm 59$ см до $699 \pm 119$ см $(p<0,05)$, вертикаль-

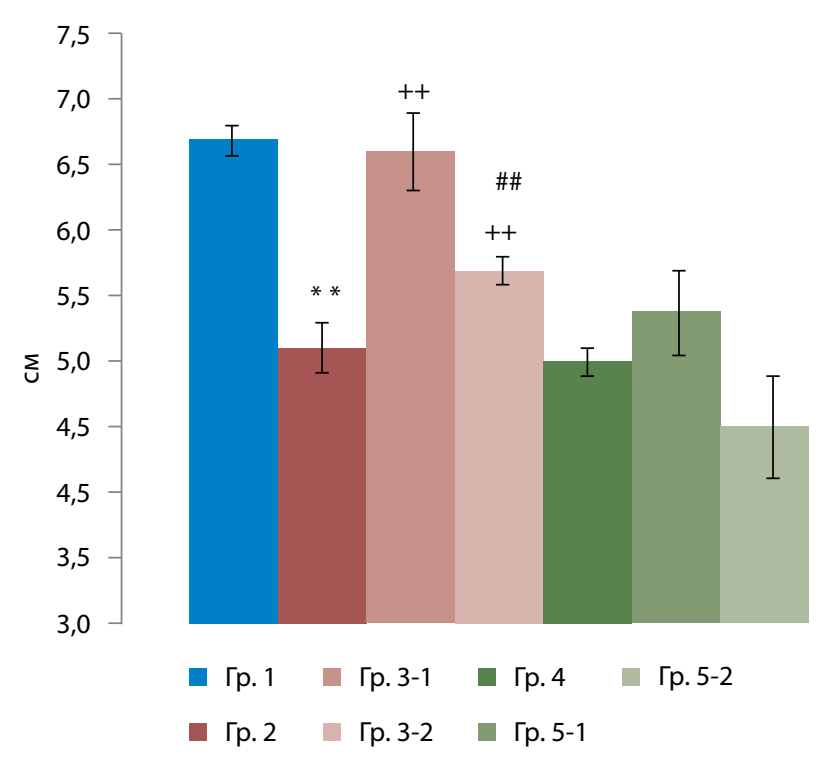

Рис. Влияние гимантана и амантадина на изменение дины шага мышей на разных стадиях развития экспериментального паркинсонического синдрома. По оси ординат: длина шага в см. Группы животных: Гр.1 - животные, которым вводили раствор $\mathrm{NaCl}$ (контроль); Гр.2- животные, которым вводили МФТП по схеме $4 \times 12$ мг/кг; Гр.3 - животные, которым вводили МФТП по схеме $4 \times 12$ и гимантан (Гр.3-1) или амантадин (Гр.3-2); Гр.4 - животные, которым вводили МФТП в режиме $4 \times 20$ мг/кг; Гр.5 - животные, которым вводили МФТП в режиме $4 \times 20$ мг/кг и гимантан (Гр.5-1) или амантадин (Гр.5-2). Статистическая значимость отличий: ** - от Гр.1

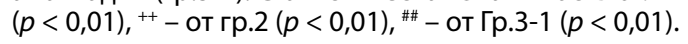


ную двигательную активность (число стоек) с 3,9 \pm 1,5 до $11,7 \pm 2,2(p<0,05)$, а также снижало время без движения с $285,6 \pm 11,8$ с до $181,7 \pm 11,5$ с $(p<0,01)$. Эти факты свидетельствуют о снижении олигокинезии у животных (табл.). При этом улучшалась координация движения животных с ПС: время спуска животного в тесте «вертикальный стержень» снижалось в 2 раза с 8,0 \pm 0,4 с до $3,9 \pm 0,4$ c $(p<0,01)$. Гимантан также предотвратил развитие ригидности у мышей на ранней стадии ПС после введения МФТП: длина шага увеличивалась с 5,1 \pm 0,2 см до $6,6 \pm 0,3$ см $(p<0,01)$ и практически достигла значений группы контрольных животных: 6,7 $\pm 0,1$ см (рис.).

Введение амантадина в дозе 20 мг/кг в аналогических условиях увеличивало длину пробега, число стоек и время без движения животных до 427,7 \pm 79,3 см, $5,6 \pm 0,5$ и 238,3 $\pm 15,3$ с, соответственно (табл.). Однако при сравнении значений этих показателей со значениями аналогичных показателей после введения гимантана наблюдались достоверные отличия $(p<0,05)$. Значение длины шага в группе животных, которым вводили МФТП $(4 \times 12$ мг/кг) и гимантан, составило $6,6 \pm 0,3$ см и было больше, чем значение длины шага $(5,7 \pm 0,1$ см) в группе животных, которым вводили МФТП $(4 \times 12$ мг/кг) и амантадин $(p<0,01)$ (рис.).

При моделировании поздней стадии ПС (Гр.4) выраженность паркинсонической симптоматики у мышей (олигокинезии и ригидности) возрастала. Длина пробега и число стоек контрольных мышей снижались с $1175 \pm 60$ см и 15,1 $\pm 1,9$ до $156 \pm 112,1$ см и $3,2 \pm 2,1$ у мышей с ПС, соответственно $(p<0,01)$. Время спуска контрольных животных в тесте «вертикальный стержень» увеличивалось с 2,8 \pm 0,5 с до 11,2 $\pm 2,4$ с $(p<0,01)$. Отмечалось также снижение длины шага контрольных животных с 6,7 $\pm 0,1$ см до 5,0 $\pm 0,1$ см у животных с ПС $(p<0,01)$. Выраженность ригидности составила 2,1 $\pm 0,1$ балла.

Предварительное ведение гимантана или амантадина животным с ПС, вызванным введением МФТП (Гр.5-1 и Гр.5-2), не приводило к значимому снижению олигокинезии и ригидности (табл., рис.).

\section{Обсуждение}

Полученный антипаркинсонический эффект гимантана на ранней клинической стадии развития ПС, возможно связан с его потенциальными нейропротекторными свойствами. Показано, что гимантан может блокировать NMDA глутаматные каналы [13], что может способствовать снижению эксайтотоксического действия глутамата в механизмах повреждения и гибели нигростриатных дофаминергических нейронов при паркинсонизме, вызванном введением МФТП.

Одним из главных механизмов гибели нейронов является повреждение ДНК, вызванное оксидативным стрессом [14, 15]. Установлено, что гимантан снижает уровень продуктов перекисного окисления липидов в мозге мышей с МФТП-индуцированным ПС [16]. При БП гибели нигростриатных дофаминергиеских нейронов может способствовать нейровоспаление, вызванное активацией микроглии, в результате чего выделяется провоспалительные цитокины: фактор некроза опухоли- $\alpha$ (ФНО- $\alpha$ ), интерлекины IL-1, IL-6, IL-10 [17]. В крови больных с болезнью Паркинсона фиксируется увеличение уровня провоспалительных цитокинов ФНО- $\alpha$, IL-1 $\beta$, IL-6 [18, 19]. Гимантан, возможно, снижает также нейровоспалительный процесс в мозге. Это предположение подтверждается результатами исследований, показывающих: уменьшение последствий воспаления, вызванного интранигральным введением липополисахарида; и снижение уровня провоспалительного цитокина IL-6 в крови после конканавалин А индуцированного воспаления у мышей [20, 21]. В исследованиях, проводимых in vitro и in vivo, было установлено, что гимантан является селективным ингибитором МАО-В [22]. Фермент МАО-В участвует в метаболизме МФТП, превращая его в конечный продукт 1-метил-4-фенилпиридиний в ионной форме $\left(М Ф \Pi^{+}\right)$, который через блокирование митохондриального комплекса I вызывает гибель нигральных дофаминергических нейронов [23, 24]. Учитывая этот факт можно предположить, что нейропротекторные

Таблица

Влияние гимантана и амантадинана параметры локомоторной активности мышей на разных стадиях развития экспериментального паркинсонического синдрома

\begin{tabular}{|c|c|c|c|}
\hline Экспериментальные группы & Длина пробега, см & Число стоек & Время без движения, с \\
\hline Гр.1. $\mathrm{NaCl}$ (Контроль) & $1175 \pm 60,3$ & $15,1 \pm 1,9$ & $176,4 \pm 12,4$ \\
\hline Гр.2. МФТП $4 \times 12$ мг/кГ & $305,4 \pm 59,1^{* *}$ & $3,9 \pm 1,5^{* *}$ & $285,6 \pm 11,8^{* *}$ \\
\hline Гр.3-1. МФТП 4 × 12 мг/кг + гимантан & $698,6 \pm 118,5^{+}$ & $11,7 \pm 2,2^{+}$ & $181,7 \pm 11,5^{++}$ \\
\hline Гр.3-2. МФТП 4 × 12 мг/кг + амантадин & $427,7 \pm 79,3^{\#}$ & $5,6 \pm 0,5^{+\#}$ & $238,3 \pm 15,3^{+\#}$ \\
\hline Гр.4. МФТП $4 \times 20$ мг/кГ & $156,2 \pm 112,1^{* *}$ & $3,2 \pm 2,1 * *$ & $264,0 \pm 51,4^{* *}$ \\
\hline Гр.5-1. МФТП 4 × 20 мг/кг + гимантан & $310,0 \pm 96,7$ & $2,0 \pm 1,0$ & $269,3 \pm 33,2$ \\
\hline Гр.5-2. МФТП 4 × 20 мг/кг + амантадин & $157,1 \pm 55,6$ & $1,2 \pm 0,4$ & $294,0 \pm 13,2$ \\
\hline
\end{tabular}

Примечание: статистическая значимость отличий (по One-Way ANOVA) обозначена ** - при сравнении с Гр.1 $(p<0,01) ;{ }^{+}-$при сравнении с Гр.2 $\left(\left(^{+}-p<0,05 ;^{++}-p<0,01\right){ }^{*}-\right.$ при сравнении с Гр.3-1 $(p<0,05)$. 
свойства гимантана обусловлены, в том числе, его способностью ингибировать этот ключевой фермент обмена медиаторных моноаминов - МАО-В.

\section{Заключение}

Таким образом, предварительное введение производных адамантана - гимантана и амантадина - при моделировании ПС ослабляет выраженность олигокинезии, мышечной ригидности и степень нарушения координации движений животных на начальной и промежуточной стадиях развития паркинсонизма. При этом гимантан оказался эффективнее в сравнении с амантадином. Однако оба препарата не оказывали значимого влияния на параметры поведенческой активности животных на поздней клинической стадии ПС.

\section{Список литературы}

1. Крыжановский Г.Н., Карабань И.Н., Магаева С.В., Кучеряну В.Г., Карабань Н.В. Болезнь Паркинсона (этиология, патогенез, клиника, диагностика, лечение, профилактика). Москва: Медицина, 2002. 372 с

2. Poewe W., Seppi K., Tanner C.M., Halliday G.M., Brundin P., Volkmann J., Schrag A.E., Lang A.E. Parkinson disease. Nat. Rev. Dis. Primers. 2017; 3: 17013. DOI: 10.1038/nrdp.2017.13

3. Olanow C.W, Tatton W.G. Etiology and pathogenesis of Parkinson's disease. Annu. Rev. Neurosci. 1999; 22: 123-144. DOI: 10.1146/ annurev.neuro.22.1.123

4. Левин О.С., Федорова Н.В. Болезнь Паркинсона. Москва: МЕДпресс-информ, 2015. 384 c.

5. Иллариошкин С.Н. Производные амантадина в лечении болезни Паркинсона. Нервные болезни. 2016; 3: 14-18.

6. Логвинов И.О., Антипова Т.А., Непоклонов А.В., Вальдман Е.А. Сравнение защитного эффекта гимантана и амантадина при действии нейротоксина 6-гидроксидофамина в культуре клеток нейробластомы человека. Экспериментальная и клиническая фармакология. 2016; 79(1): 12-14.

7. Непоклонов А.В., Капица И.Г., Иванова Е.А., Воронина Т.А., Вальдман Е.А. Изучение эффектов гимантана на модели ранней (“домоторной” стадии болезни Паркинсона у крыс. Экспериментальная и клиническая фармакология. 2012; 75(11): 3-6.

8. Иванова Е.А., Капица И.Г., Вальдман Е.А., Воронина Т.А. Противопаркинсоническая активность гимантана на модели гемипаркинсонического синдрома у крыс. Бюллетень экспериментальной биологии и медицины. 2015; 159(3): 362-365.

9. Вальдман Е.А., Капица И.Г., Калинина А.П., Иванова Е.А., Воронина Т.А. Изучение эффектов комбинации гимантана и пирибедила на модели МФТП-индуцированного паркинсонического синдрома у мышей линии C57BL/6. Обзоры по клинической фармакологии и лекарственной терапии. 2019; 17(2): 35-40. DOI: $10.17816 /$ RCF17235-40

10. Ugrumov M.V., Khaindrava V.G., Kozina E.A., Kucheryanu V.G., Bocharov E.V., Kryzhanovsky G.N., Kudrin V.S., Narkevich V.B., Klodt P.M., RayevskyK.S., Pronina T.S. Modeling of presymptomatic and symptomatic stages of parkinsonism in mice. Neuroscience. 2011; 181: 175-188. DOI: 10.1016/j.neuroscience.2011.03.007

11. Бочаров Е.В., Кучеряну В.Г., Крыжановский Г.Н., Бочарова О.А., Кудрин В.С., Белорусцева С.А. Влияние комплексного фитоадаптогена на МФТП-индуцированный паркинсонический синдром у мышей. Бюллетень экспериментальной биологии и медицины. 2006; 141(5): 555-558.

12. Кучеряну В.Г., Ветрилэ Л.А., Захарова И.А. Влияние антител к глутамату при интраназальном введении на экспериментальный паркинсонический синдром. Патологическая физиология и экспериментальная терапия. 2018; 62(4): 250-253. DOI: $10.25557 / 0031-2991.2018 .04 .250-253$

13. Елшанская М.В., Соболевский А.И., Вальдман Е.А., Ходоров Б.И. Взаимодействие потенциального противопаркинсонического средства производного адамантана с ионными каналами глутаматных рецепторов NMDA подтипа. Экспериментальная и клиническая фармакология. 2001: 64(1): 18-21.

14. Пальцын А.А., Свиридкина Н.Б. О регенерации мозга (Лекция I). Патогенез. 2017; 15(4): 74-80. DOI: 10.25557/GM.2018.4.9753

15. Wyss-Coray T. Ageing, neurodegeneration and brain rejuvenation. Nature. 2016; 539(7628): 180-186. DOI: 10.1038/nature20411

16. Иванова Е.А., Капица И.Г. Золотов Н.Н., Вальдман Е.А., Непоклонов А.В., Колясникова К.Н., Воронина Т.А. Влияние гимантана на уровень продуктов перекисного окисления в головном мозге при экспериментальном паркинсоническом синдроме. Фармакокинетика и фармакодинамика. 2016; 79(3): 9-12.

17. Кучеряну В.Г., Бочаров Е.В., Крыжановский Г.Н., Бочарова О.А, Полещук В.В. Механизмы нейродегенерации при болезни Паркинсона. Активация микроглии. Патогенез. 2012; 10(3): 30-34.

18. Бочаров Е.В., Крыжановский Г.Н., Полещук В.В, Кучеряну В.Г., Горожанская Э.Г., Сандалов Ю.Г., Ильенко В.А., Бочарова O.A. Нарушение иммунной и антиоксидантной защиты при болезни Паркинсона. Патогенез. 2012; 10(1): 34-38.

19. Pochmann D., Peccin P.K., da Silva I.R.V., Dorneles G.P., Peres A., Nique S., Striebel V, Elsner V.R. Cytokine modulation in response to acute and chronic aquatic therapy intervention in Parkinson disease individuals: A pilot study. Neurosci. Lett. 2018; 674: 30-35. DOI: 10.1016/j.neulet.2018.03.021

20. Таллерова А.В., Иванова Е.А., Капица И.Г., Коваленко Л.П., Вальдман Е.А., Воронина Т.А. Влияние противопаркинсонического препарата гимантан на уровень цитокинов в эксперименте. Иммунология. 2013; 34(5): 254-257.

21. Ivanova E.A., Kapitsa I.G., Nepoklonov A.V., Kokshenev I.I., Val'dman E.A., Voronina T.A. Anti-inflammatory activity of hemantane on peripheral inflammation and lipopolysaccharideinduced neuro-inflammation models. Pharm. Chem. J. 2014; 47(10): 517-520. DOI:10.1007/s11094-014-0994-x

22. Вальдман Е.А., Воронина Т.А., Аксенова ЈI.Н., Бунеева О.А., Медведев А.Е. Влияние нового противопаркинсонического препарата гимантана на активность моноаминоксидаз. Экспериментальная и клиническая фармакология. 2003; 66(5): 3-5.

23. Saporito MS, Heikkila RE, Youngster SK, Nicklas WJ, Geller HM. Dopaminergic neurotoxicity of 1-methyl-4-phenylpyridinium analogs in cultured neurons: relationship to the dopamine uptake system and inhibition of mitochondrial respiration. J. Pharmacol. Exp. Ther. 1992; 260(3): 1400-1409.

24. Przedborski S., Vila M. MPTP: a review of its mechanisms of neurotoxicity. Clin. Neurosci. Res. 2001; 1: 407-418. DOI: 10.1016/ S1566-2772(01)00019-6

\section{References}

1. Kryzhanovsky G.N., Karaban I.N., Magayeva S.V., Kucheryanu V.G., Karaban N.V. [Parkinson's disease]. Moscow: Meditsina, 2002. 336 p. (in Russian)

2. Poewe W., Seppi K., Tanner C.M., Halliday G.M., Brundin P., Volkmann J., Schrag A.E., Lang A.E. Parkinson disease. Nat. Rev. Dis. Primers. 2017; 3: 17013. DOI: 10.1038/nrdp.2017.13

3. Olanow C.W, Tatton W.G. Etiology and pathogenesis of Parkinson's disease. Annu. Rev. Neurosci. 1999; 22: 123-144. DOI: 10.1146/annurev.neuro.22.1.123

4. Levin O.S., Fedorova N.B. [Parkinson's disease]. Moscow: MEDpress-inform, 2015. 384 p. (in Russian) Illarioshkin S.N. [Adamantane derivatives in the treatment of Parkinson's disease]. Nervnye bolezni. [Nervous diseases]. 2016; 3: 14-18. (in Russian)

5. Logvinov I.O., Antipova T.A., Nepoklonov A.V., Valdman E.A. [Comparison of Cytoprotective effects of hemantane and amantadine under conditions of 6-hydroxydopamine neurotoxin action on cultured human neuroblastoma cells]. Eksperimental'naya I klinicheskaya farmakologiya. [Experimental and Clinical Pharmacology]. 2016; 79(1): 12-14. (in Russian)

6. Nepoklonov A.V., Kapitsa I.G., Ivanova E.A., Voronina T.A., Val'dman E.A. [Study of hemantane effects in rats on a model of early (premotor) stage of Parkinson's disease]. Eksperimental'naya I klinicheskaya farmakologiya. [Experimental and Clinical Pharmacology]. 2012; 75(11):3-6. (in Russian)

7. Ivanova E.A., Kapitsa I.G., Val'dman E.A., Voronina T.A. [Anti-parkinsonian activity of hemantane on a model of hemiparkinsoniansyndrome in rats]. Byulleten' ehksperimental'noi biologii i medici- 
ny. [Bulletin of Experimental Biology and Medicine]. 2015; 159(3): 380383. (in Russian)

8. Val'dman E.A., Kapitsa I.G., Kalinina A.P., Ivanova E.A., Voronina T.A. [The study of the effects of the combination of Himantane and Piribedil on a model of MPTP-induced parkinsonian syndrome in C57BL/6 mice]. Obzory po klinicheskoi farmakologii i lekarstvenoi terapii. [Clinical Pharmacology and Drug Therapy Reviews]. 2019; 17(2):35-40. DOI: 10.17816/RCF17235-40 (in Russian)

9. Ugrumov M.V., Khaindrava V.G., Kozina E.A., Kucheryanu V.G., Bocharov E.V., Kryzhanovsky G.N., Kudrin V.S., Narkevich V.B., Klodt P.M., RayevskyK.S., Pronina T.S. Modeling of presymptomatic and symptomatic stages of parkinsonism in mice. Neuroscience. 2011; 181: 175-188. DOI: 10.1016/j.neuroscience.2011.03.007

10. Bocharov E.V., Kucheryanu V.G., Kryzhanovsky G.N. Belorustseva S.A., Bocharova O.A., Kudrin V.S. [Effect of complex phytoadaptogen on MPTP-induced Parkinson's syndrome in mice]. Byulleten' ehksperimental'noi biologii i mediciny. [Bulletin of Experimental Biology and Medicine]. 2006; 141(5): 560-563. (in Russian)

11. Kucheryanu V.G., Vetrile L.A., Zakharova I.A. [The effect of intranasal administration of glutamate antibody on experimental parkinsonian syndrome]. Patologicheskaya fiziologiya I eksperimental'naya terapiya. [Pathological Physiology and Experimental Therapy]. 2018; 62(4):250253. DOI: 10.25557/0031-2991.2018.04.250-253 (in Russian)

12. Elshanskaya M.V., Sobolevskii A.I., Val'dman E.A., Khodorov B.I. [Interaction of the new adamantane derivative A-7 - a potential antiparkinsonian drug with NMDA receptor channels]. Eksperimental'naya I klinicheskaya farmakologiya. [Experimental and Clinical Pharmacology]. 2001: 64 (1): 18-21. (in Russian)

13. Paltsyn A.A., Sviridkina N.B. [About regeneration of the brain (Lecture I)]. Patogenez. [Pathogenesis]. 2017; 15(4): 74-80. DOI: 10.25557/ GM.2018.4.9753 (in Russian)

14. Wyss-Coray T. Ageing, neurodegeneration and brain rejuvenation. Nature. 2016; 539(7628): 180-186. DOI: 10.1038/nature20411

15. Ivanova E.A., Kapitsa I.G., Zolotov N.N., Valdman E.A., Nepoklonov A.V., Kolyasnikova K.N., Voronina T.A. [Effects of Hemantane upon the level of lipid peroxidation in brain in experimental parkinsonian syndrome]. Farmakinetika i farmadinamika. [Pharmakinetika and Pharmadinamica]. 2016; 3: 9-12. (in Russian)

16. Kucheryanu V.G., Bocharov E.V., Kryzhanovsky G.N., Bocharova O.A. [The mechanisms of neurodegeneration in Parkinson's disease. Microglia activation]. Patogenez. [Pathogenesis]. 2012; 10(3): 30-34. (in Russian)

17. Bocharov E.V., Kryzhanovsky G.N., Poleschuk V.V., Kucheryanu V.G., Gorojanskaya E.G., Sandalov Yu.G., Ilienko V.A., Bocharova O.A. [Immune and antioxidant disorders in Parkinson's disease]. $\mathrm{Pa}$ togenez. [Pathogenesis]. 2012; 10(1): 34-38. (in Russian)

18. Pochmann D., Peccin P.K., da Silva I.R.V., Dorneles G.P., Peres A., Nique S., Striebel V, Elsner V.R. Cytokine modulation in response to acute and chronic aquatic therapy intervention in Parkinson disease individuals: A pilot study. Neurosci. Lett. 2018; 674: 30-35. DOI: 10.1016/j.neulet.2018.03.021

19. Tallerova A.V., Ivanova E.A., Kapitsa I.G., Kovalenko L.P., Val'dman E.A.,Voronina T.A. [Influence of antiparkinsonian drug hemantane on the level of cytokines in experimental models. Immunologia. [Immunology]. 2013; 34(5): 254-7. (in Russian)

20. Ivanova E.A., Kapitsa I.G., Nepoklonov A.V., Kokshenev I. I., Val'dman E.A., Voronina T.A. Anti-inflammatory activity of hemantane on peripheral inflammation and lipopolysaccharideinduced neuro-inflammation models. Pharm. Chem. J. 2014; 47(10): 517-520. DOI:10.1007/s11094-014-0994-x

21. Val'dman E.A., Voronina T.A., Aksenova L.N., Buneeva OA., Medvedev A.E. [The effect of the new antiparkinsonian drug hemantane on monoamine oxidase activity]. Eksperimental'naya I klinicheskaya farmakologiya. [Experimental and Clinical Pharmacology]. 2003; 66(5): 3-5. (in Russian)

22. Saporito MS, Heikkila RE, Youngster SK, Nicklas WJ, Geller HM. Dopaminergic neurotoxicity of 1-methyl-4-phenylpyridinium analogs in cultured neurons: relationship to the dopamine uptake system and inhibition of mitochondrial respiration. J. Pharmacol. Exp. Ther. 1992; 260(3): 1400-1409.

23. Przedborski S., Vila M. MPTP: a review of its mechanisms of neurotoxicity. Clin. Neurosci. Res. 2001; 1: 407-418. DOI: 10.1016/S15662772(01)00019-6

\section{Сведения об авторах:}

Воронина Наталья Александровна - аспирантка лаборатории общей патологии нервной системы Федерального государственного бюджетного научного учреждения «Научно-исследовательский институт общей патологии и патофизиологии»; https://orcid.org/0000-0002-1764-6444

Кучеряну Валериян Григорьевич - доктор медицинских наук, главный научный сотрудник общей патологии нервной системы Федерального государственного бюджетного научного учреждения «Научно-исследовательский институт общей патологии и патофизиологии»; http://orcid.org/0000-0002-5071-3581

Капица Инга Геннадьевна - кандидат биологических наук, старший научный сотрудник лаборатории психофармакологии Федерального государственного бюджетного научного учреждения «Научно-исследовательский институт фармакологии имени В.В.Закусова»; https://orcid.org/0000-0003-4487-0991

Воронина Татьяна Александровна - доктор медицинских наук, профессор, руководитель лаборатории психофармакологии Федерального государственного бюджетного научного учреждения «Научно-исследовательский институт фармакологии имени В.В.Закусова»; https://orcid.org/0000-0001-7065-469X 